\title{
IMPLEMENTASI PENGATURAN HAK KONSTITUSIONAL ANAK DALAM PEMENUHAN WAJIB BELAJAR 12 TAHUN DI PROVINSI BALI
}

Oleh

\author{
Ni Made Ari Yuliartini Griadhi
}

\begin{abstract}
Abstrak
Pembangunan sumber daya manusia mempunyai peranan yang sangat penting bagi kesuksesan dan kesinambungan Pembangunan Nasional. Oleh karena itu pembangunan dan peningkatan kualitas sumber daya manusia mutlak harus diperhatikan dan dirancang dengan seksama berdasarkan pemikiran yang matang. Program wajib belajar 12 tahun merupakan kebijakan yang diambil Pemerintah untuk peningkatan kualitas Sumber Daya Manusia Indonesia. Perlu kiranya dipikirkan hal-hal yang dapat menunjang serta masalah - masalah apa saja yang akan timbul, mulai dari perencanaan serta payung hukum yang jelas, sosialisasi pada masyarakat, sampai dengan pelaksanaan di lapangan, hal tersebut harus terencana dengan sebaik-baiknya. Penulisan ini mengkaji sejauh mana regulasi serta pengimplementasian pengaturan terhadap hak konstitusional anak dalam pemenuhan wajib belajar 12 tahun di Provinsi Bali pasca diterbitkannya Peraturan Gubernur Bali No. 40 Tahun 2017. Metode yang digunakan dalam penulisan ini adalah sosiolegal menggunakan data sekunder yang berupa bahan hukum primer, sekunder, dengan menggunakan teknik analisis yaitu teknik deskriptif, evaluasi dan argumentasi serta kemudian mengelaborasi terhadap fakta-fakta yang terjadi. Peraturan secara Nasional yang terkait dengan pengaturan dibidang pendidikan diantaranya: Undang-Undang Nomor 20 Tahun 2003 Tentang Sistem Pendidikan Nasional, Tap MPR No.9 tahun 2007 Tentang Anggaran Dana Pendidikan, Undang-Undang Nomor 32 Tahun 2004 Tentang Otonomi Daerah, Peraturan Pemerintah Nomor 32 Tahun 2007 tentang Pembagian Kewenangan Antara Pemerintah Pusat dan Daerah Otonom, Peraturan Pemerintah Nomor 19 Tahun 2005 tentang Standar Nasional Nasional Pendidikan, Peraturan Daerah Nomor 1 Tahun 2004 Tentang Rencana Strategic Pembangunan Provinsi, Peraturan Daerah Nomor 1 Tahun 2007 Tentang Anggaran Pendapatan Belanja Daerah Provinsi serta Permendiknas No 17 Tahun 2017 tentang Prosedur dan Tata Cara Penerimaan Peserta Didik Baru Tahun Ajaran 2017/2018. Pengimplementasian pengaturan terhadap hak konstitusional anak dalam pemenuhan wajib belajar 12 tahun di Provinsi Bali pasca diterbitkannya Peraturan Gubernur No. 40 Tahun 2017 sudah terpenuhi. Dimana diterbitkanya Peraturan Gubernur tersebut untuk mengatasi kendala dari pengimplementasian Permendikbud Nomor 17 Tahun 2017. Dengan adanya Pergub tersebut calon siswa yang tercecer dari ketentuan zonasi dalam Permendiknas bisa tercover lagi dengan membuka pendaftaran gelombang kedua. Serta Pergub tersebut telah mengakomodir terpenuhinya hak Konstitusional anak dalam pemenuhan wajib belajar 12 tahun di provinsi Bali dimana diberikan peluang bagi anakanak yang berasal dari keluarga kurang mampu diterima di sekolah-sekolah negeri menurut ketentuan yang berlaku serta bagi siswa yang berprestasipun diberikan peluang untuk diterima disekolah-sekolah negeri
\end{abstract}

\section{I.PENDAHULUAN}

Pembukaan Undang-Undang Dasar 1945 secara tegas menyatakan bahwa salah satu tujuan Negara Republik Indonesia adalah mencerdaskan kehidupan bangsa. Penjabaran dari tujuan tersebut telah tercantum pada' Pasal 31 Ayat (1) - (5) UUD NRI 1945, dimana disyaratkan di dalamnya setiap Warga Negara diberikan hak untuk mendapatkan 
pendidikan serta Pemerintah mengembangkan suatu Pendidikan Nasional untuk menciptakan Manusia Indonesia yang berpendidikan dimana biaya pendidikan dialokasikan $20 \%$ dari APBN dan APBD. Pendidikan merupakan salah satu usaha setiap bangsa untuk meningkatkan kualitas sumber daya manusia sehingga membantu memperlancar pelaksanaan Pembangunan Nasional Indonesia. Usaha pendidikan ini ditujukan untuk mengembangkan cipta, rasa, dan karsa yang ada sehingga setiap manusia diharapkan mampu menghadapi tantangan sesuai dengan tuntutan perubahan kehidupan lokal, nasional, maupun kehidupan global. Kuntjoro Purbopranoto menyatakan bahwa pendidikan merupakan proses atau usaha setiap bangsa yang tak terputus-putus sifatnya di dalam segala tingkat kehidupan manusia, sesuai dengan perkembangan masyarakat dan kebudayaan yang bertujuan untuk mencapai kesempurnaan dan kedewasaan pada manusia, agar dengan kesadaran dan tanggung jawab dapat menghadapi pelbagai persoalan hidup. ${ }^{1}$

Merujuk pada Konstitusi menegaskan bahwa tiap-tiap Warga Negara berhak mendapatkan pengajaran. Pendidikan juga merupakan pengamalan terhadap Hak Asasi dari seluruh Warga Negara Indonesia. Sejalan dengan hal tersebut, Pasal 5 ayat (1) Undang-Undang Nomor 20 Tahun 2003 tentang Sistem Pendidikan Nasional juga menegaskan bahwa setiap warga Negara mempunyai hak yang sama untuk memperoleh pendidikan yang bermutu. ${ }^{2}$ Pasal 6 ayat (1) nyamengamanatkan bahwa setiap warga negara yang berusia 7-15 tahun wajib mengikuti pendidikan dasar. Pasal 34 ayat (2) nya juga menyebutkan bahwa Pemerintah dan Pemerintah Daerah menjamin terselenggaranya wajib belajar minimal pada jenjang pendidikan dasar tanpa memungut biaya. Pasal 11 ayat (2) UU Sistem Pendidikan Nasional menyebutkan bahwa Pemerintah dan Pemerintah Daerah wajib menjamin tersedianya dana gunaterselenggaranya pendidikan bagi setiap warga negaranya yang berusia 7 sampai 15 tahun. Konsekuensi dari amanat Undang-Undang tersebut adalah pemerintah dan pemerintah daerah wajib memberikan layanan pendidikan bagi seluruh peserta didik pada tingkat pendidikan dasar (Sekolah Dasar dan Sekolah Menengah Pertama) serta satuan pendidikan lain yang sederajat.

Mengamanatkan ketentuan Pasal 34 ayat (4) Undang-Undang Nomor 20 Tahun 2003 tentang Sistem Pendidikan Nasional, yaitu menetapkan Peraturan Pemerintah tentang Wajib Belajar diatur lebih lanjut dalam PP Nomor 47 tahun 2008 tentang Wajib Belajar. Wajib Belajar merujuk pada suatu kebijakan yang mengharuskan warga negara dalam usia sekolah mengikuti pendidikan sekolah sampai jenjang tertentu dan pemerintah berupaya memberikan dukungan sepenuhnya agar warga negara peserta wajib belajar dapat mengikuti pendidikan sekolah. Wajib Belajar dalam Sistem Pendidikan Nasional adalah pendidikan dasar gratis 9 tahun. Sedangkan Pemerintah kemudian mencanangkan wajib belajar 12 tahun.

Program wajib belajar adalah program pendidikan gratis yang dicanangkan pemerintah untuk anak-anak usia sekolah sampai dengan jenjang yang telah ditentukan, yakni SMA. Sebenarnya hambatan-hambatan yang dijumpai di tengah masyarakat yangdapat menghambat anak dalam mengenyam wajib belajar bukan menjadi suatu alasan untuktidak menyekolahkan anak, namun sejauhmana peran pemerintah daerah dapat memfasilitasi danmewujudkan pendidikan wajib belajar tersebut agar dapat berjalan dengan baik dan tepatsasaran.

Dengan adanya Otonomi Daerah, pemerintah daerah memiliki wewenang untuk menentukan sampai jenjang mana pelaksanaan Program Pendidikan Wajib Belajar sekolah menengah di daerah akan dilaksanankan atau dijalankan.Pemerintah Provinsi Bali telah menyikapi dengan mengeluarkan Peraturan Gubernur terkait wajib belajar 12 tahun yaitu Peraturan Gubernur No. 40 Tahun 2017. Berdasarkan pemaparan tersebut di atas, maka dapat dirumuskan permasalahan sebagai berikut :

1. Bagaimana pengaturan terhadap hak konstitusional anak dalam pemenuhan wajib belajar 12 tahun.

2. Pengimplementasian pengaturan terhadap hak konstitusional anak dalam pemenuhan wajib belajar 12 tahun di Provinsi Bali

Metode yang digunakan dalam penulisan ini adalah sosiolegal menggunakan data sekunder yang berupa bahan hukum primer, sekunder, dengan menggunakan teknik analisis yaitu teknik deskriptif, evaluasi dan argumentasi serta kemudian mengelaborasi terhadap fakta-fakta yang terjadi.

\section{PEMBAHASAN}

2.1 Pengaturan hak konstitusional anak dalam pemenuhan wajib belajar 12 tahun. 
Menurut John Locke, Hak Asasi Manusia adalah hak-hak yang diberikan langsung oleh Tuhan Yang Maha Pencipta sebagai hak yang kodrati. Dengan hak-hak dasar yang melekat pada diri manusia tersebut, maka manusia dapat hidup layak sebagai manusia. Kuntjoro Purbopranoto mengartikan hak asasi manusia sebagai hak-hak yang dimiliki manusia menurut kodratnya, yang tidak dapat dipisahkan dari hekekatnya dan karena itu bersifat suci. ${ }^{4}$ Pasal 1 angka 1 Undang-Undang No. 39 tahun 1999 tentang HAM dan Undang-Undang No. 26 tahun 2000 tentang Pengadilan HAM, yang dimaksud dengan hak asasi manusia adalah seperangkat hak yang melekat pada hakekat dan keberadaan manusia sebagai mahkluk Tuhan Yang Maha Esa dan merupakan anugerahnya yang wajib dihormati, dijunjung tinggi, dan lindungioleh negara hukum, pemerintah dan setiap orang, demi kehormatan serta perlidungan harkat dam martabat manusia. $^{5}$

Pembukaan UUD 1945 menyatakan bahwa tujuan nasional adalah untuk melindungi segenap bangsa dan seluruh tumpah darah Indonesia, memajukan kesejahteraan umum, mencerdaskan kehidupan bangsa, dan ikut melaksanakan ketertiban dunia berdasarkan kemerdekaan, perdamaian abadi, dan keadilan sosial.Dengan demikian, dapat dipahami bahwa salah satu tujuan didirikannya Negara Kesatuan Republik Indonesia (NKRI) adalah untuk mencerdaskan kehidupan bangsa. Adanya tujuan nasional tersebut mengakibatkan bahwa kewajiban mencerdaskan bangsa melekat pada eksistensi negara. Dengan kata lain, bahwa untuk mencerdaskan kehidupan bangsalah maka Negara Indonesia dibentuk.Untuk mewujudkan tujuan nasional tersebut, terutama tujuan mencerdaskan kehidupan bangsa, harus dicapai melalui proses pendidikan. Pendidikan pada dasarnya merupakan fitrah manusia sebagai makhluk yang berakal dan berpikiran. Proses pendidikan itu sendiri berlangsung sejak dalam kandungan sampai ke liang lahat dan bisa didapat di mana saja dan kapan saja. Dalam pemenuhannya di lapangan, pendidikan dapat dilakukan melalui jalur formal, nonformal, dan informal pada setiap jenjang dan jenisnya. ${ }^{6}$

Berdasarkan ketentuan UUD 1945 jelaslah bahwa mendapatkan pendidikan merupakan hak setiap warga negara. Atau dengan kata lain, hak mendapatkan pendidikan merupakan hak setiap warga negara yang dijamin dalam konstitusi, yang lazim dipahami sebagai hak konstitusional warga negara. Hak konstitusional adalah hak-hak dasar yang kemudian diadopsi dalam konstitusi yang meliputi hak asasi manusia dan hak warga negara yang dijamin dalam UUD 1945 dan berlaku bagi setiap Warga Negera Indonesia. Hak-hak warga negara untuk mendapatkan pendidikan tidak hanya menimbulkan kewajiban negara untuk menghormati dan melindungi, tetapi menimbulkan tanggung jawab negara untuk memenuhi hak warga negara tersebut. Agar tanggung jawab negara dapat dipenuhi dengan baik maka UUD 1945 misalnya, melalui Pasal 31 Ayat (2) mewajibkan kepada pemerintah untuk membiayainya. Bahkan, negara harus memprioritaskan anggaran pendidikan sekurang-kurangnya $20 \%$ dari APBN serta APBD untuk memenuhi kebutuhan penyelenggaraan pendidikan nasional.

Dalam UUDNegara Republik Indonesia 1945 BAB XIII pasal 31 telah jelas dinyatakan bahwa

Ayat 1 :Setiap warga Negara berhak mendapatkan pendidikan(perubahan keempat)

Ayat 2 : Setiap warga Negara wajib mengikuti pendidikan dasar dan pemerintah wajib membiayainya(perubahan keempat)

Ayat 3 :Pemerintah mengusahakan dan menyelenggarakan satu sistem pendidikan nasional, yang meningkatkan keimanan dan ketakwaan serta akhlak mulia dalam rangka mencerdaskan kehidupan bangsa, yang diatur dengan undang-undang (perubahan keempat)

Ayat 4 :Negara memprioritaskan anggaran pendidikan sekurang-kurangnya dua puluh persen dari anggaran pendapatan dan belanja Negara serta dari anggaran pendapatan dan belanja daerah untuk memenuhi kebutuhan penyelenggaraan pendidikan nasional. (perubahan keempat)

Ayat 5 :Pemerintah memajukan ilmu pengetahuan dan teknologi dengan menjunjung tinggi nilai-nilai agama dan persatuan bangsa untuk kemajuan peradaban serta kesejahteraan umat manusia. (perubahan keempat).

Hal ini mengisyaratkan bahwa Negara memiliki peran, serta tanggung jawab yang luar biasa dalam mencerdaskan kehidupan bangsanya. Pendidikan merupakan salah satu hak yang paling asasi yang dimiliki oleh setiap orang. Pendidikan yang baik akan menciptakan sumber 
daya manusia yang memiliki kompetensi tinggi dalam menjawab era globalisasi yang penuh dengan tantangan dan kompetisi. Pendidikan membawa pengaruh yang sangat besar terhadap pengembangan hidup setiap individu dan masyarakat melalui peningkatan kemampuan intelektual kemampuan-kemampuan emosi dalam menghadapi berbagai hal, serta kemampuankemampuan mototrik dalam menggiatkan dan mengkoordinasikan gerakan individu. Pendidikan merupakan suatu proses yang tidak bisa dipisahkan dengan manusia yang menjadi subyek dan obyek dari upaya pendidikan itu sendiri. ${ }^{7}$

Pentingnya pendidikan ini bagimasyarakat tergambar dari peranan yang dibawa dalam kegiatan pendidikan dalam kaittanya dengan perkembangan seseorang. Redja Mudyahardjo menyatakan bahwa pendidikan secara langsung mendorong perubahan kemampuan seseorang, kulitas kemampuan kognitif, afektif dan psikomotor, dari ketiga peningkatan tersebut dapat dipergunakan untukebih meningkatkan taraf hidupnya sebagai manusia, warga masyarakat dan Warga Negara. ${ }^{8}$

Perkembangan masyarakat sangat bergantung pada kondisi pendidikan masyarakatnya sebagai potensi pendidikan diwilayah tersebut. Sifatnya mutlak dalam kehidupan, baik dalam kehidupan seseorang, keluarga, maupun bangsa dan negara. Maju mundurnya suatu bangsa ditentukan oleh majunya mundurnya pendidikan bangsa itu. Plato menjelaskan bahwa pendidikan dikonsepsikan sebagai proses penyiapan manusia sebagai warga pendukung terwujudnya negara ideal. ${ }^{9}$

Terkait dengan pengaturan terhadap hak konstitusional anak dalam pemenuhan wajib belajar 12 tahun guna membentuk Manusia Indonesia yang cerdas dan mampu berpartisipasi secara aktif dalam tataran dunia global yang merupakan amanat dari Konstitusi. Amanat ini dijawantahkan dalam Psal Undang-Undang Dasar 1945 pasal 31 ayat (2) dan Undang-Undang No. 20 Tahun 2003 tentang Sistem Pendidikan Nasional beserta peraturan di bawahnya yang menjamin hak dasar memperoleh pendidikan bermutu bagi setiap Warga Indonesia dan Pemerintah membiayainya. UU Sisdiknas hanya memberikan batasan kewenangan pemerintah dalam membiayai pendidikan dasar sampai tingkat SMP. Padahal, untuk meningkatkan kualitas manusia Indonesia yang cerdas, dan selaras dengan janji Nawacita Presiden Jokowidodo, dibutuhkan peningkatan kualitas pendidikan, terutama meningkatkan akses pendidikan warga negara pada jenjang SMA. Menteri Koordinator Bidang Pembangunan Manusia dan Kebudayaan Puan Maharani mengatakan, pelaksanaan program wajib belajar 12 tahun akan dimulai Juni 2015.Menurut Puan, pelaksanaan program wajib belajar 12 tahun sesuai janji kabinet kerja. Dengan adanya program wajib belajar 12 tahun, semua anak Indonesia wajib masuk sekolah dan pemerintah wajib membiayai serta menyediakan segala fasilitasnya. ${ }^{10}$ Kementerian Pendidikan dan Kebudayaan akan memulai rintisan Wajib Belajar atau Wajar 12 tahun pada 2016, dengan harapan pada 2019 tercapai sejumlah target, seperti tersedianya perpustakaan di semua sekolah $(100 \%)^{11}$.

Usaha masyarakat sipil untuk mengadakan Judicial Review ke Mahkamah Konstitusi agar membatalkan pembatasan usiapendidikan dasar yang dibiayai pemerintah hanya sampai jenjang SMP sudah kandas dengan dikeluarkannya keputusan MahkamahKonstitusi Perkara No.92/ PUU-XII/2014. Keputusan MK ini menyatakan bahwa tentang kriteria usia pendidikan dasar yang dibiayai Pemerintah merupakan sebuah persoalan hukum yang sifatnya terbuka dan tergantung dari para pembuat hukum, yaitu terutama Legislatif dan Pemerintah. Karena itu, pelaku utama yang mampu mewujudkan kebijakan pendidikan dasar 12 tahun sekarang berada di tangan anggota Parlemen dan Pemerintah. Pemerintah dan Parlemen perlu segera membangun kesepakatan bersama agar pendidikan dasar sampai tingkat SMU yang menjadi hak setiap warga dapat terwujud dan Negara membiayainya dengan mengesahkan sebuah Undang-Undang untuk melaksanakan amanat mencerdaskan kehidupan bangsa ini. Program seperti Pendidikan Menengah Universal, Kartu Indonesia Pintar dan alokasi dana BOS untuk membantu meningkatkan akses siswa Indonesia pada jenjang pendidikan menengah, meskipun baik, bukanlah sebuah kebijakan yang dapat berlangsung terus menerus.Mantan Wakil Ketua Mahkamah Konstusi Achmad Sodiki mengatakan program pendidikan minimal yang harus diikuti Warga Negara Indonesia merupakan tanggung jawab pemerintah dan pemerintah daerah merupakan kebijakan hukum terbuka atau open legal policy.Dia mengatakan hal itu terkait penolakan mahkamah konstitusi terhadapuji materi Pasal 6 ayat (1) UU No. 20 Tahun 2003 tentang Sistem Pendidikan Nasional (Sisdiknas) terkait 
wajib belajar 9 tahun yang dilayangkan Network For Education Watch Indonesia (NEW Indonesia) atau Jaringan Pemantau Pendidikan Indonesia (JPPI). Keputusan MK yang menolak revisi UU Sisdiknas dengan alasan open legal policy itu menimbulkan perbedaan pandangan dengan para pemohon. Untuk itu open legal policy perlu di analisis yang kritis. Karena itu, pemerintah perlu bekerjasama dengan Parlemen dan anggota legislatif yang lainnya untuk merevisi UU No. 20 Tahun 2003 tentang Sisdiknas sehingga kriteria pendidikan dasar bisa diubah dari jenjang SMP ke SMA. Dalam jangka pendek, untuk mendesak pemerintah daerah (Gubernur, walikota, bupati) mendukung program Wajib Belajar 12 Tahun, pemerintah bisa bekerjasama dengan Pemda untuk merealisasikan pelaksanaan Peraturan Pemerintah No. 47 Tahun 2008 tentang Wajib Belajar sehingga masing-masing daerah dapat melaksanakan program Wajib Belajar 12 tahun dengan menggunakan dana dari Anggaran Pendapatan dan Belanja Daerah. Dalam waktu yang sama, Pemerintah memfasilitasi inisiatifpublik dari masyarakat sipil yang ingin terlibat dalam memberikan kesempatan pendidikan bermutu bagi setiap warga negara sesuai dengan cakupan bidang dan tugasnya sehingga pendidikan menengah universal bisa dinikmati oleh semua warga negara tanpa kecuali.

Tahun 2016 dikeluarkanlah Peraturan Mendikbud RI Nomor 19 Tahun 2016 tentang Program Indonesia Pintar. Program Indonesia Pintar (PIP) adalah bantuan berupa uang tunai dari pemerintah yang diberikan kepada peserta didik yang orang tuanya tidak dan/atau kurang mampu membiayai pendidikan. Kartu Indonesia Pintar (KIP) adalah kartu yang diberikan kepada anak usia 6 sampai 21 tahun sebagai identitas untuk mendapatkan manfaat PIP. Pada Pasal 2 Permendikbud RI Nomor 19 Tahun 2016 ini disebutkan tentang tujuan dari adanya Program Indonesia Pintar PIP, yang mana PIP bertujuan untuk:

a. meningkatkan akses bagi anak usia 6 (enam) sampai dengan 21 (dua puluh satu) tahun untuk mendapatkan layanan pendidikan sampai tamat satuan pendidikan menengah dalam rangka mendukung pelaksanaan pendidikan menengah universal/rintisan wajib belajar 12 (dua belas) tahun;

b. mencegah peserta didik dari kemungkinan putus sekolah (drop out) atau tidak melanjutkan pendidikan akibat kesulitan ekonomi; dan/atau c. menarik siswa putus sekolah (drop out) atau tidak melanjutkan agar kembali mendapatkan layanan pendidikan di sekolah, sanggar kegiatan belajar, pusat kegiatan belajar masyarakat, lembaga kursus dan pelatihan, satuan pendidikan nonformal lainnya, atau balai latihan kerja.

Menyongsong Tahun Pelajaran Baru 2017/2018 pada Bulan Juli 2017, Kementerian Pendidikan dan Kebudayaan telah mengeluarkan Peraturan Menteri Pendidikan dan Kebudayaan Nomor 17 Tahun 2017 tentang Penerimaan Peserta Didik Baru Pada Taman Kanak-Kanak, Sekolah Dasar, Sekolah Menengah Pertama, Sekolah Menengah Atas, Sekolah Menengah Kejuruan, Atau Bentuk Lain Yang Sederajat. Permendikbud ini bertujuan untuk memberikan acuan dan pedoman bagi Satuan Pendidikan dalam menyelenggarakan proses penerimaan siswa baru agar dilakukan secara objektif, akuntable, transparan, dan tanpa deskriminasi guna meningkatkan akses layanan pendidikan. Pasal 13 ayat (1) Permendikbud disebutkan bahwa Seleksi calon peserta didik baru kelas 10 (sepuluh) SMA, SMK, atau bentuk lain yang sederajat mempertimbangkan kriteria dengan urutan prioritas sesuai daya tampung berdasarkan ketentuan rombongan belajar sebagai berikut:

a. jarak tempat tinggal ke Sekolah sesuai dengan ketentuan zonasi;

b. usia sebagaimana dimaksud dalam Pasal 7 ayat (1) hurufa;

c. SHUN SMP atau bentuk lain yang sederajat; dan

d. prestasi di bidang akademik dan non-akademik yang diakui Sekolah.

Ayat (2) nya menyebutkan bahwa Jarak tempat tinggal ke Sekolah sesuai dengan ketentuan zonasi sebagaimana dimaksud pada ayat (1) huruf a, dikecualikan bagi calon peserta didik baru pada SMK atau bentuk lain yang sederajat. Dalam ayat (3) nya diatur bahwa Khusus calon peserta didik pada SMK atau bentuk lain yang sederajat, selain mengikuti seleksi sebagaimana dimaksud pada ayat (1) huruf b, huruf c, dan huruf d, Sekolah dapat melakukan seleksi bakat dan minat sesuai dengan bidang keahlian/program keahlian/kompetensi keahlian yang dipilihnya dengan menggunakan kriteria yang ditetapkan Sekolah dan institusi pasangan/asosiasi profesi.

Pasal 14 ayat (1) Permendikbud menyatakan bahwa Sekolah yang diselenggarakan oleh masyarakat, dapat melakukan seleksi selain 
sebagaimana dimaksud dalam Pasal 11 sampai dengan Pasal 13 dan/atau melalui tes bakat skolastik atau tes potensi akademik. Pada Bagian Keempat diatur mengenai Sistem Zonasi yaitu dalam Pasal 15 ayat (1) nya menyebutkan bahwa Sekolah yang diselenggarakan oleh Pemerintah Daerah wajib menerima calon peserta didik yang berdomisili pada radius zona terdekat dari sekolah paling sedikit sebesar $90 \%$ (sembilan puluh persen) dari total jumlah keseluruhan peserta didik yang diterima. Ayat (2) nya menyebutkan bahwa domisili calon peserta didik sebagaimana dimaksud pada ayat (1) berdasarkan alamat pada kartu keluarga yang diterbitkan paling lambat 6 (enam) bulan sebelum pelaksanaan PPDB. Ayat (3) nya menyebutkan bahwa Radius zona terdekat sebagaimana dimaksud pada ayat (1) ditetapkan oleh pemerintah daerah sesuai dengan kondisi di daerah tersebut berdasarkan jumlah ketersediaan daya tampung berdasarkan ketentuan rombongan belajar masing-masing sekolah dengan ketersediaan anak usia sekolah di daerah tersebut. Ayat (4) nya mengatur bagi sekolah yang berada di daerah perbatasan provinsi/kabupaten/kota, ketentuan persentase dan radius zona terdekat sebagaimana dimaksud pada ayat (1) dapat diterapkan melalui kesepakatan secara tertulis antarpemerintah daerah yang saling berbatasan. Ayat (5) nya mengatur bahwa Sekolah yang diselenggarakan oleh pemerintah daerah dapat menerima calon peserta didik melalui:

a. jalur prestasi yang berdomisili diluar radius zona terdekat dari sekolah paling banyak $5 \%$ (lima persen) dari total jumlah keseluruhan peserta didik yang diterima;

b. jalur bagi calon peserta didik yang berdomisili diluar zona terdekat dari sekolah dengan alasan khusus meliputi perpindahan domisili orangtua/ wali peserta didik atau terjadi bencana alam/ sosial, paling banyak 5\% (lima persen) dari total jumlah keseluruhan peserta didik yang diterima. Pasal 16 ayat (1) mengatur bahwa SMA, SMK, atau bentuk lain yang sederajat yang diselenggarakan oleh pemerintah daerah provinsi wajib menerima peserta didik baru yang berasal dari keluarga ekonomi tidak mampu yang berdomisili dalam satu wilayah daerah provinsi paling sedikit 20\% (dua puluh persen) dari jumlah keseluruhan peserta didik yang diterima. Ayat (2) nya menyebutkan bahwa Peserta didik baru yang berasal dari keluarga ekonomi tidak mampu sebagaimana dimaksud pada ayat (1) dibuktikan dengan Surat Keterangan Tidak Mampu (SKTM) atau bukti lainnya yang diterbitkan oleh pemerintah daerah. Ayat (3) nya menyebutkan bahwa apabila peserta didik memperoleh SKTM dengan cara yang tidak sesuai dengan ketentuan perolehannya, akan dikenakan sanksi pengeluaran dari Sekolah. Dalam ayat (4) Sanksi sebagaimana dimaksud pada ayat (3) diberikan berdasarkan hasil evaluasi Sekolah bersama dengan komite sekolah, dewan pendidikan, dan dinas pendidikan provinsi sesuai dengan ketentuan peraturan perundang-undangan. Ketentuan zonasi sebagaimana dimaksud dalam Pasal 15 tidak berlaku bagi SMK ( Pasal 17 Permendikbud No 17 Tahun 2017 ). Pasal 24nya mengatur tentang rombongan belajar dimana ditentukan bahwa Jumlah peserta didik dalam satu Rombongan Belajar diatur sebagai berikut: Pada huruf C SMA dalam satu kelas berjumlah paling sedikit 20 (dua puluh) peserta didik dan paling banyak 36 (tiga puluh enam) peserta didik; SMK dalam satu kelas berjumlah paling sedikit 15 (lima belas) peserta didik dan paling banyak 36 (tiga puluh enam) peserta didik. Pasal 35 nya menyebutkan bahwa Pemerintah daerah wajib membuat kebijakan daerah sebagai tindak lanjut atas Peraturan Menteri ini dengan berasaskan objektif, akuntabel, transparan, tanpa diskriminasi, berkeadilan, dan memperhatikan terhadap kemampuan orang tua/wali peserta siswa. Pasal 36 Penerapan ketentuan tentang zonasi dan sistem PPDB secara daring/online dilakukan secara bertahap sesuai dengan kesiapan masing-masing daerah. Sehungga dari ketentuan Permendikbud tersebut ada 4 jalur peneimaan peserta diidik baru yaitu: 1. Jalur miskin 20\%, 2. jalur Prestasi 20\%, 3. Jalur Lokal 10\% dan 4. Jalur regular 50\%.

Pada Tahun Ajaran 2018/2019 Permendikbud tersebut diganti dengan Permendikbud Nomor 14 Tahun 2018 tentang Penerimaan Peserta Didik Baru Taman KanakKanak (TK), Sekolah Dasar (SD), Sekolah Menengah Pertama (SMP), Sekolah Menengah Atas (SMA), Sekolah Menengah Kejuruan (SMK), atau Bentuk Lain yang Sederajat karena dianggap sudah kurag sesuai. Penerimaan Peserta Didik Baru (PPDB) menurut Permendikbud ini bertujuan menjamin penerimaan peserta didik baru berjalan secara obyektif, transparan, akuntabel, nondiskriminatif dan berkeadilan dalam rangka mendorong peningkatan akses pendidikan. Asas nondiskriminasi tidak berlaku bagi sekolah yang khusus melayani peserta didik dari kelompok gender atau agama tertentu. 
Sistem Zonasi masih diterapkan dalam Permendikbud ini, dimana system ini masih menimbulkan hal-hal yang penting untuk dibicarakan kedepannya. Menteri Pendidikan dan kebudayaan Muhadjir Efendy menegaskan bahwa system Zonasi dilakukan demi pemerataan pendidikan di Indonesia. Pasal 16 Permendikbud No. 14 Tahun 2018 mengatur tentang Zonasi yaitu sekolah harus menerima siswa baru yang berdomisili pada radius paling dekat dengan sekolah yang dilihat berdasarkan alamat yang tertera pada Kartu Keluarga yang diterbitkan paling lambat 6 bulan sebelum masa Penerimaan Peserta Didik Baru. Sistem Zonasi ini diberlakukan untuk jenjang SD, SMP, SMA sedangkan SMK dibebaskan dari sistem zonasi. Sistem zonasi dapat menghilangkan favoritisme sekolah karena akan mendapatkan sekolah sesuai dengan daerah zonasinya, hanya saja ini menimbulkan problem dimana jika Pemerintah belum memfasilitasi sekolah-sekolah secara merata. Hal ini dapat dikatakan akan membatasi hak seseorang untuk mendapatkan pendidikan yang lebih baik. ${ }^{12}$

\subsection{Pengimplementasian Pengaturan Terhadap Hak Konstitusional Anak Dalam Pemenuhan Wajib Belajar 12 Tahun Di Provinsi Bali Pasca Diterbitkannya Peraturan Gubernur No. 40 Tahun 2017.}

Hasil Penelitian yang dilakukan penulis tahun 2017 didapatkan bahwa Peraturan yang dibuat dalam Permendikbud No.17 Tahun 2017 tersebut yang dibuat sangat ideal setelah diterapkan di lapangan menemui banyak kendala yang mana siswa tidak bisa tertampung lantaran karena zona yang berbeda, hal ini terjadi pada daerah yang padat penduduknya. Menyikapi hal tersebut DPRD Bali dengan mengundang Pemerintah Daerah ( Gubernur Bali) melakukan pertemuanpertemuan membahas masalah ini dan lahirlah Peraturan Gubernur Bali No.40 Tahun 2017 yang melabrak Permendikbud No.17 Tahun 2017. Kepala Dinas Pendidikan Provinsi Bali, Tia Kusuma Wardhani mengatakan ada tiga hal penting yang dituangkan dalam Pergub sesuai hasil rapat kerja Gubernur dengan DPRD Bali, yaitu:

1. Semua siswa miskin meskipun nilainya rendah harus diterima di sekolah negeri terkait kebijakan nasional wajib belajar 12 tahun;

2. Siswa berprestasi agar diterima tanpa melihat domisilinya;

3. Persyaratan KK bisa diabaikan untuk menampung calon siswa yang masih tercecer.
Mengenai Rombongan belajar (rombel) menurut beliau diijinkan 40 orang perkelas di daerahdaerah padat penduduk. Rombel yang melebihi ketentuan maksimal 36 siswa ini juga bisa diberlakukan SMA/SMK swasta. Kalau ternyata masih belum menampung seluruh siswa yang tercecer sekolah dijinkan untuk menerapkan Double shift atau melaksanakan kejar paket. Jangan sampai ada anak yang tidak mendapatkan tempat disekolah. Senada dengan Kadisdik, Kepala Biro Hukum dan HAM Setda Provinsi Bali, I Wayan Sugiada menegaskan bila Pergub memang memberikan keberpihakan kepada siswa miskin. Kendati, siswa miskin tetap harus melampirkan surat keterangan miskin, memiliki salah satu dari Kartu Keluarga Sejahtera/Kartu Indonesia Sehat/Kartu Indonesia Pintar, serta ada home visit oleh satuan pendidikan. Begitu jugasiswa berprestasi harus membuktikan prestasinya lewat sertifikat maksimal 3 tahun terakhir. ${ }^{13}$ Setelah dikeluarkannya Pergub No 40 Tahun 2017, Dinas Pendidikan (Disdik) Provinsi Bali segera membuka Penerimaan Peserta Didik Baru (PPDB) SMA/SMK Negeri gelombang kedua. Menyusul telah diberlakukannya Pergub No.40 Tahun 2017 tentang PPDB SMA dan SMK Negeri. Dari hasil wawancara dengan di SMAN I Denpasar didapatkan data bahwa berkaitan dengan Permendikbud No. 17 Tahun 2017 di SMAN I Denpasar berkaitan dengan PPBD tahun 2017, dinyatakan bahwa idealisme nya sudah bagus seperti mengurai kemacetan dengan zonasi namun kurang setuju dengan tarung bebas di ruang lingkup kabupaten atau kota karena dengan hal ini akan menimbulkan anggapan bahwa siswa akan sekedar lulus toh juga akan diterima karena rumahnya dekat dengan sekolah yang diinginkan. Untuk siswa miskin tetap dibantu sekaligus juga siswa penyandang disabilitas juga direkomendasi, dimana pendaftaran lalu hanya 1 orang yang mendaftar. Untuk siswa berprestasi juga sangat diapresiasi. Jalur NUN disarankan agar diberi tarung bebas dalam ruang lingkup provinsi. Diluar provinsi baru dicanangkan 5\%. SMAN 1 Denpasar tetap menjalankan prosedur yang ada seperti PPDB kemarin Zonasi/local mengalokasikan 36 siswa (10\%) untuk jalur siswa miskin dan cacat fisik diformasikan 76 orang, jalur prestasu $20 \%$, jalur NUN 180 orang (50\%) namun dikarenakan jalur siswa miskinnya tidak mencukupi katanya dialihkan ke jalur NUN (NEM). Untuk menentukan zonasi SAMN 1 Denpasar menggunakan google maps sehingga tidak ada 
masalah hanya saja untuk kedepannya diharapkan untuk jalus zonasi lebih baik menggunakan system radius jaraak rumah ke sekolah dibandingkan kabupaten dan kota. Terkait dengan sistem kuota terkait dengan jumlah kelas, SMAN 1 Denpasar nantinya akan tetap menjalankan sesuai peraturan dari kemendikbud. Dengan diberlakukaannya sistem zonasi pada pendaftaran gelombang pertama ada beberapa calon siswa yang tercecer, SMAN I Denpasar membuka kembali dan menerima sebanyak 26 siswa yang tercecer dimana 5 dari 26 tersebut terkait kebijakan anak kandung ( anak guru) dari sekolah ini (sesuai Pergub 40 Tahun 2017). Jadi total siswa yang diterima di SMAN I Denpasar pada tahun 2017 adalah 386 siswa termasuk yang tercecer.

Dalam mengimplementasikan kebijakan pemerintah mengenai wajib belajar 12 tahun, SMAN I tidak menemui kendala dikarenakan dari segi kualitas siswa sudah ada yang mengatur, dan sebagai pihak sekolah juga menjalankan sesuai aturan. Adapun jika ada kesulitan finansial SMAN 1 Denpasar sudah memiliki "sumbangan Komite" untuk membantu kegiatan sekolah dan sudah masuk dalam rencana kerja anggaran. Ada catatan yang disampaikan bahwa sebagai pihak sekolah menginginkan juga agar kualitas sekolah dapat terjaga. Maka dari itu seharusnya dapat mengakomodir keinginan sekolah untuk diadakannya seleksi bebas untuk jalur NUN yang ruang lingkupnya adalah Provinsi

Selain di SMAN 1 Denpasar wawancara juga dilakukan di SMAN 3 Denpasar. Dari hasil wawancara dinyatakan bahwa ketentuan Permendikbud No. 17 Tahun tersebut adalah baik sudah jelas bagaimana teknis penerimaan siswa baru, sesuai dengan 4 jalur yang sudah ditetapkan yaitu: 1. Jalur NEM sebesar 50\% dengan ketentuan menerima 5\% dari luar daerah. 2. Jalur prestasi sebesar 20\% 3. Jalur Miskin sebesar 20\%. 4. Jalur Lokal sebesar 10\% Sesuai Permen tersebut adapun jumlah kapasitas siswa perkelas adalah 36 siswa dengan total jumlah kelas adalah 8 kelas sehingga daya tampung SMAN 3 Denpasar berkisar 288 siswa sedangkan tahun ini yang mendaftar kisaran 300 orang yang menyebabkan tidak semua pelamar diterima.Terkait dengan system zonasi yang diterapkan tersebut setiap SMA memiliki kebijakan atau sistem tersendiri, SMAN 1 Denpasar menggunakan aplikasi google map untuk SMAN 3 berkordinasi dengan lingkungan yang terdekat yakni contohnya kelurahan Sumerta dan
Sumerta Kelod, selanjutnya ditetapkan kreteria sistem penerimaan siswa baru dan diakomodir. Secara perkembangannya sitem tersebut tidak menuai protes atau kritik dari masyarakat. Terkait dengan kuota siswa tersebut terkait dengan penambahan ruang kelas baru, saat ini SMAN 3 denpasar belum ada wacana untuk mengadakan pembaangunan ruang kelas baru. Untuk tahun ini SMAN 3 Denpasar menerima 6 siswa yang tercecer, dimana penerimaannya tersebut berdasarkan prosentasi daya tamping sekolah apakah ditemukan kuota yang masih dapat terisi atau tidak dan tentu saja dalam proses tersebut dikordinasikan kepada kemendikbud hal ini diatur sesuai dengan Surat Edaran Gubernur. Cara mengatasi dengan melihat atau meninjau ulang adakah kuota atau daya tampung yang bisa diisi dan atau mengalihkan siswa tersebut ke dalam kelas baru yang dibuat dengan fasilitas yang ada seperti lab kimia/lab bahasa.

Penerimaan Peserta Didik Baru Tahun Jaran 2018/2019 msh menemui kendala-kendala terkait dengan system zonasi yang msh diatur dalam Permendikbud Nomor 14 Tahun 2018 tentang Penerimaan Peserta Didik Baru Taman KanakKanak (TK), Sekolah Dasar (SD), Sekolah Menengah Pertama (SMP), Sekolah Menengah Atas (SMA), Sekolah Menengah Kejuruan (SMK), atau Bentuk Lain yang Sederajat. Ketua DPRD Provinsi Bali I Nyoman Adi Wiryatama mengatakan banyak orangtua siswa mengeluhkan penerimaan peserta didik baru (PPDB) tahun ajaran 2018-2019, dimana masih banyak calon siswa dari keeluarga miskin tidak bisa diterima di sekolah negeri karena daya tamping ruang kelas tidak cukup terutama untuk sekolah-sekolah yang berada di daerah padat penduduk akbat dari system zonasi yang diterapkan. Dikatakan juga bahwa pemerintah perlu turun tangan memberikan solusi untuk memastikan calon siswa tersebut bisa diterima di sekolah negeri.Sebagai solusi untuk menyiasati keterbatasan daya tampung ruang kelas, Adi Wiryatama mendorong pemerintah dan pihak sekolah untuk membuka kelas pagi dan siang (double shift). Solusi lain atas masalah ini adalah dengan menambah jumlah siswa dalam setiap kelas, tapi hal tersebut akanterbentur dengan aturan yang hanya membatasi jumlah siswa maksimal 36 orang setiap kelas. Solusi dengan membuka sekolah pagi dan siang dinilai tak menyalahi aturan.Dengan membuka sekolah pagi dan siang, tentu hal tersebut membutuhkan tambahan tenaga pendidik. Karena itu, perlu diadakan 
pengangkatan guru kontrak.yang gajinya disiapkan dalam APBD. ${ }^{14}$

Pelaksanaan wajib belajar 12 tahun dengan system zonasi ini pada dasarnya baik untuk dilaksanakan hanya saja masih menimbulkan problem untuk beberapa sekolah terutama sekolah-sekolah pinggiran yang belummempunyai fasilitas memadai, serta sekolah-sekolah yang berada pada zonasi yang padat penduduknya perlu diadakan penambahan kelas supaya bisa menampung calon sisiwa yang ada di zonasi yang bersangkutan sehingga benang kusut PPDB tahun ini tidak kembali terjadi pada tahun ajaran berikutnya serta hak pendidikan dari Warga Negara dapat terpenuhi dengan baik.

\section{KESIMPULAN DAN SARAN \\ 3.1. Kesimpulan.}

1. Pengaturan terhadap hak konstitusional anak dalam pemenuhan wajib belajar 12 tahun belum ada aturan secara khusus menyatakan adanya wajib belajar 12 tahun. Akan tetapi sebagai suatu kebijakan terbuka dari pemerintah kebijakan pemerintah untuk menerapkan wajib belajar 12 tahun dapat dilihat dari Ketentuan UUD Negara RI Tahun 1945 yaitu dalam Pasal 31 tentang pendidikan, kemudian daapat dilihat dalam UU Sisdiknas yaitu Undang-Undang Nomor 20 Tahun 2003 tentang Sistem Pendidikan Nasional yang telah juga diyudicial review dimana MK berpendapat bahwa penentuan usia pendidikan dasar merupakan kebijakan terbuka dari pemerintah. Peraturan Mendikbud RI Nomor 19 Tahun 2016 tentang Program Indonesia Pintar, didalamnya juga meengatur tentang wajib belajar 12 tahun.Kemudian bisa juga dilihaat dari adanya Permendikbud Nomor 17 Tahun 2017 yang mengatur tentang penerimaan peserta didik baru yang mana mengatur tentang mekanisme penerimaan peserta didik baru. Provinsi Bali juga mengeluarkan peraturan dalam bentuk Peraturan Gubernur Bali Nomor 40 Tahun 2017 yang di dalamnya mendukung pelaksanaan wajib belajar 12 tahun yang dilaksanakan oleh Pemerintah. Pada Tahun Ajaran 2018/2019 Permendikbud tersebut diganti dengan Permendikbud Nomor 14 Tahun 2018 tentang Penerimaan Peserta Didik Baru Taman KanakKanak (TK), Sekolah Dasar (SD), Sekolah Menengah Pertama (SMP), Sekolah Menengah Atas (SMA), Sekolah Menengah Kejuruan (SMK), atau Bentuk Lain yang Sederajat
2. Pengimplementasian pengaturan terhadap hak konstitusional anak dalam pemenuhan wajib belajar 12 tahun di Provinsi Bali tahun ajaran 2017/2018 pasca diterbitkannya Peraturan Gubernur No. 40 Tahun 2017 sudah terpenuhi. Dimana diterbitkanya Peraturan Gubernur tersebut untuk mengatasi kendala dari pengimplementasian Permendikbud Nomor 17 Tahun 2017. Dengan adanya Pergub tersebut calon siswa yang tercecer dari ketentuan zonasi dalam permendiknas bisa tercover lagi dengan membuka pendaftaran gelombang kedua. Serta Pergub tersebut telah mengakomodir terpenuhinya hak Konstitusional anak dalam pemenuhan wajib belajar 12 tahun di provinsi Bali dimana diberikan peluang bagi anakanak yang berasal dari keluarga kurang mampu diterima di sekolah-sekolah negeri menurut ketentuan yang berlaku serta bagi siswa yang berprestasipun diberikan peluang untuk diterima disekolah-sekolah negeri. Pada Tahun ajaran 2018/2019 dengan digantinya Permendikbud Nomor 17 Tahun 2017 dengan Permendikbud Nomor 14 Tahun 2018 tentang Penerimaan Peserta Didik Baru Taman Kanak-Kanak (TK), Sekolah Dasar(SD), Sekolah Menengah Pertama (SMP), Sekolah Menengah Atas (SMA), Sekolah Menengah Kejuruan (SMK), atau Bentuk Lain yang Sederaja, yang masih menerapkan system zonasi masih menyisakan kendala-kendala dalam pelaksanaannya. Pelaksanaan wajib belajar 12 tahun dengan system zonasi ini pada dasarnya baik untuk dilaksanakan hanya saja masih menimbulkan problem untuk beberapa sekolah terutama sekolah-sekolah pinggiran yang belum mempunyai fasilitas memadai, serta sekolahsekolah yang berada pada zonasi yang padat penduduknya perlu diadakan penambahan kelas supaya bisa menampung calon sisiwa yang ada di zonasi yang bersangkutan sehingga benang kusut PPDB tahun ini tidak kembali terjadi pada tahun ajaran berikutnya serta hak pendidikan dari Warga Negara dapat terpenuhi dengan baik.

\subsection{Saran.}

1. Agar bisa lebih menjamin hak-hak konstitusional anak dalam pemenuhan wajib belajar 12 tahun diharapkan Pemerintah merevisiUU Sistem Peendidikan Nasional yang nantinya secara tegas mengatur wjib belajar itu sendiri selama 12 Tahun. 


\section{DAFTAR PUSTAKA}

\section{Buku-Buku}

Abdul Rahmat, 2014, Pengantar Pendidikan, Gorontalo: Ideas Publishing.

Ahmad Sukardja, Hukum Tata Negara Dan Hukum Administrasi Negara, Jakarta, Sinar Grafika, Dewa Gede Palguna, Pengaduan Konstitusional (constitusional Complaint), Jakarta; Sinar Grafika,h. 112Kuntjoro Purbopranoto, 1976, Hak-Hak Azasi Manusia dan Pancasila, Pradnya Paramita, Jakarta.

Driyarkara, 1980, Pendidikan, Yogyakarta: Kanisius.

Enid Campbell, et.al., 1988, legal Research, Materials and Methods, Sydney: The Law Book Company Limited.

Suparlan Suhartono, 2005, Filasat Pendidikan, ARRUZZ Media.

Jacques Delors, 1996, "Learning: The Treasure Within" dikutip dari Ali MuhdiAmnur(ed), Konfigurasi Politik Pendidikan Nasional, Pustaka Fahima, Yogyakarta, 2007.

M Sirozi, Politik pendidikan, "Dinamika Hubungan Antara kepentinganKekuasaan dan Praktik Wajib Belajar 12 Tahun", 2005, Raja Grafindo Persada..

Morin, Edgar, 2005, Tujuh Materi Penting Bagi Dunia Pendidikan, Yogyakarta: Kanisius.

Kartono, Kartini, 1997, Tinjauan Holistik Mengenai Tujuan Pendidikan Nasional, Jakarta:Pradnya Paramita.

Soedijarto, 2008, Landasan dan Arah pendidikan Nasional Kita, Jakarta : PT Kompas MediaNusantara.

Ishaq, Isjoni, 2006. Membangun Visi Bersama "Aspek-Aspek Penting Dalam ReformasiPendidikan".Jakarta : Yayasan Obor Indonesia.

Marhaendra Wija Atmaja, 2014, "Metode Penelitian Hukum dalam Penyusunan Naskah Akademik Rancangan Peraturan Perundangundangan", Denpasar: Progran Studi Magister Ilmu Hukum Program Pasca Sarjana Universitas Udayana, hlm. 12. Risalah ini merujuk pada Soelistyowati Irianto, 2012, "Memperkenalkan kajian sosiolegal dan implikasi metodologisnya", dalam Adriaan W. Bedner, dkk (Eds.), Kajian Sosio-Legal, Denpasar: Pustaka Larasan; dan Soelistyowati Irianto, 2011, "Praktik Penelitian Hukum: Perspektif Sosiolegal", dalam Soelistyowati Irianto dan Shidarta, (Eds.), Metode Penelitian Hukum: Knstelasi dan Refleksi, Jakarta: Yayasan Pustaka Obor Indonesia.

Sudikno Mertokusumo, 1996, Mengenal Hukum, Liberty, Yogyakarta.

Peter Mahmud Marzuki, 2005, Penelitian Hukum, Prenada Media, Jakarta.

Riduan, 2004, Metode\& Teknik Menyusun Tesis, Bina Cipta, Bandung.
Rudy, dan Budiyono, 2014, Konstitusi Dan HAM, Bandar Lampung, Justice Publisher.

Syaeful Sagala, 2009, Administrasi Pendidikan Kontemporer, Bandung, Alfabeta.

\section{Jurnal}

Asep Tapipi Yani, "Wajar” Kebijakan Publik Untuk Pendidikan Orang Miskin, Bandung: Anggota IKAPI.

Jimly Asshiddiqie, 2010, "Gagasan Negara Hukum Indonesia", Jurnal. Volume III.

Internet Bali Post portal berita, www.balipost.com/ news/2017/07/04/.../Pergub-PPDB-SMASMKNegeri,Calon...html, diakses tanggal 10 Oktober 2017

Direktorat Pembinaan SMK, Direktorat Jendral Pendidikan Dasar dan Menengah Kementerian Pendidikan dan Kebudayaan, https://psmk.kemdikbud.go.id/.../kemdikbudupayakanwajib-belajar-12-tahun-melal..., diakses tanggal 11 Oktober 2017

https://orinaru.wordpress.com/2012/10/08/ penegakan-hak-asasi-manusia-ham-diduniapendidikan-indonesia/, diakses pada 1010-2017.

Mahfud MD, http://aceh.tribunnews.com/2012/09/ 03/pendidikan-hak-konstitusional, diakses pada 5-10-2017.

Kompas.com13/01/2015.

Faiq yahyah, 2018, https://medium.com/.../ permendikbud-no-14-tahun-2018-zonasisekolah-atau-zonasi-...diakses tanggal 1 agustus 2018.

Anonimus, https://www.liputan6.com > Regional > Bali Nusra, diakses tanggal 3 agustus 2018

\section{Peraturan Perundang-undangan}

2. Undang-undang Nomor 20 Tahun 2003 Tentang Sistem Pendidikan Nasional.

3. Tap MPR No.9 tahun 2007 Tentang anggaran dana Pendidikan

4. Undang-undang Nomor 32 Tahun 2004 Tentang Otonomi Daerah

5. Peraturan Pemerintah Nomor 32 Tahun 2007 tentang Pembagian Kewenangan Antara Pemerintah Pusat dan Daerah Otonom.

6. Peraturan Pemerintah Nomor 19 Tahun 2005 tentang Standar Nasional Pendidikan.

7. Peraturan Menteri Pendidikan Dan Kebudayaan Republik Indonesia Nomor 19 Tahun 2016 Tentang Program Indonesia Pintar.

8. Permendiknas No 17 Tahun 2017 tentang Prosedur dan Tata Cara Penerimaan Peserta Didik Baru Tahun Ajaran 2017/2018

9. Peraturan Gubernur No. 40 Tahun 2017 tentang Wajib Belajar 12 tahun di Provinsi Bali.

10.Permendikbud Nomor 14 Tahun 2018 tentang Penerimaan Peserta Didik Baru Taman KanakKanak (TK), Sekolah Dasar (SD), Sekolah Menengah Pertama (SMP), Sekolah Menengah Atas (SMA), Sekolah Menengah Kejuruan (SMK), atau Bentuk Lain yang Sederajat. 